\title{
The Study of the Dependence of Labor Efficiency on the Level of Staff Investment Attractiveness
}

\author{
Nikolay A. Nikolaev \\ Ural State University of Economics \\ line 2-name of organization, acronyms acceptable \\ Yekaterinburg, Russia \\ wagner83@mail.ru
}

\begin{abstract}
The paper presents the author's approach to the definition of the concept of the staff investment attractiveness. Based on the analysis, the system-forming ele-ments of the concept of the staff investment attractiveness have been identified; the author's approach to the definition of the concept of the staff investment at-tractiveness has been formulated. The political and economic essence of the con-cept of the staff investment attractiveness has been determined. A methodological approach to assessing the staff investment attractiveness has been developed. Empirical studies of the impact of investment attractiveness on the effectiveness of investment in staff have been provided. The dependence of the effectiveness of investments in staff on two main factors has been established: the investment attractiveness of employees and the type of organizational and economic rela-tions that develops between the employee and the employer in the investment process. Based on the established dependence, methodological recommendations to improve the efficiency of investments in staff based on the management of its investment attractiveness have been developed.
\end{abstract}

Keywords - the concept of staff investment attractiveness; the ratio of the concept of staff investment attractiveness with the concepts of labor; human capital, human resources, methodological approach to assessing the employee and staff invest-ment attractiveness; the effectiveness of investment in staff; dependence of investment efficiency on the staff investment attractiveness; increasing the staff investment attractiveness.

\section{INTRODUCTION}

For survival and development in a modern highly competitive economy, enterprises need to continuously improve their activities, increase the competi-tiveness of goods and services, and master technical, technological, and organiza-tional innovations. This requires the owners and management of Russian enter-prises to form and use effective staff management tools aimed at continuous professional development, labor motivation, commitment to corporate values, active search and implementation of innovations.

Obviously, increasing the motivation, qualifications, and innovative activi-ty of employees requires the implementation of appropriate investments in them. For the most rational and efficient use of investment resources, the owner and management need tools to increase the efficiency of investments in staff based on the adoption of economically sound management decisions.

To date, the concept of investment attractiveness is considered mainly in relation to the enterprise, region, industry, markets, and other objects not related to staff in the economic literature. At the same time, the staff of the enterprise can also act as an investment object and generate income for entities that invest in it. In a few studies devoted to assessing and improving the staff investment at-tractiveness, the investment attractiveness of an employee is considered as a set of features characterizing its development potential and significantly affecting the formation of investment risks. These signs include: the employee's innovative abilities, the possible dynamics of the increment of individual human capital, the type of employee's innovative behavior, the effectiveness of the function per-formance [1]. However, the existing approaches to determining and assessing the staff investment attractiveness do not take into account the assessment of the physical and mental health of a person, his/her business and personal reputation, the ability to build the necessary relationships with people, the risks of changing the main socioeconomic interests of a person, and other factors important for as-sessing investment attractiveness, without which a comprehensive assessment of the staff investment attractiveness is impossible, which means the validity and minimization of risks about the existence of an investment in staff. Today, one of the main reasons for reducing the interest of enterprise managers in investing in staff is the high risks of such investments. Employees, having mastered the com-petencies they need, having received material and social benefits from the enter-prise, can leave the enterprise without having recouped the funds invested in their development. Methodological issues of assessing the risks of investment in staff are also poorly developed in modern economic science. 
The definitions of the concept of investment attractiveness

Thus, the need to increase the efficiency of investments in staff to ensure the survival and long-term development of enterprises under the high competition and the insufficient development of methodological tools for managing its investment attractiveness determine the relevance of the scientific problem of de-veloping methodological provisions for assessing and increasing the staff invest-ment attractiveness.

The purpose of the work is to study the dependence of labor efficiency on the level of the staff investment attractiveness.

The tasks of the study:

1. The definition of the staff investment attractiveness.

2. Development of a methodological approach to assessing the staff in-vestment attractiveness.

3. Study of the impact of the staff investment attractiveness on invest-ment efficiency.

4. Development of guidelines for improving the staff investment attrac-tiveness.

\section{THE DEFINITION OF THE STAFF INVESTMENT ATTRACTIVENESS}

V.N. Belkin in The Theory of Human Capital of the Organization identifies four main stages of the study of the essence of economic phenomena:

1. Assigning a name to a phenomenon using terms adopted in the corre-sponding subject field of science.

2. The definition of the concept that designates the phenomenon, that is, the definition of the content of the studied economic phenomenon by highlighting its necessary and sufficient properties, allowing attributing objects to this concept and nothing more.

3. The definition of the political and economic essence of the concept un-der consideration as a category, that is, those organizational and economic rela-tions that cause and characterize this phenomenon. In order to determine the political and economic essence of the phenomenon, it is necessary to determine the subjects and objects of relations, i.e. identify between whom and on what subject these relations are formed [2].

The author of this paper shares the logic of the study of the essence of economic phenomena proposed by V.N. Belkin and he will continue to use it to study the concept of the staff investment attractiveness of the staff.

In order to determine the essence of the economic phenomenon of the staff investment attractiveness, it is necessary to define the concept of investment attractiveness in the context of the study, in relation to the object under consider-ation.

Today, there is no single understanding of the term of investment attrac-tiveness in the scientific community. in the works of domestic and foreign researchers are shown in Table 1.

TABLE I. DEFINITIONS OF THE INVESTMENT ATTRACTIVENESS CONCEPT

\begin{tabular}{|c|c|c|}
\hline No. & Definition & Author \\
\hline 1 & $\begin{array}{l}\text { Investment attractiveness is a set of } \\
\text { signs, characteristics of various } \\
\text { aspects of the activity of investment } \\
\text { objects, which signal to the investor } \\
\text { about the possible effectiveness and } \\
\text { probability of achieving the goal. }\end{array}$ & T.A. Korkina [1] \\
\hline 2 & $\begin{array}{l}\text { Investment attractiveness is a set of } \\
\text { objective signs, properties, means, and } \\
\text { opportunities that determine the } \\
\text { potential solvent demand for } \\
\text { investments. }\end{array}$ & L.S. Valinurova [3] \\
\hline 3 & $\begin{array}{l}\text { Investment attractiveness is a } \\
\text { generalized description of the } \\
\text { advantages and disadvantages of } \\
\text { investing in certain areas and objects } \\
\text { from the perspective of a particular } \\
\text { investor. }\end{array}$ & I.A. Blank [4] \\
\hline 4 & $\begin{array}{l}\text { Investment attractiveness is } \\
\text { determined by the combination of } \\
\text { properties of the external and internal } \\
\text { environment of the investee, which } \\
\text { determine the possibility of a } \\
\text { boundary transition of investment } \\
\text { resources. }\end{array}$ & A. Mozgoev [5] \\
\hline 5 & $\begin{array}{l}\text { Investment attractiveness is the } \\
\text { existence of such investment } \\
\text { conditions that affect the investor's } \\
\text { preferences in choosing a particular } \\
\text { investment object. }\end{array}$ & V.A. Mashkin [7] \\
\hline 6 & $\begin{array}{l}\text { Investment attractiveness is a } \\
\text { combination of various objective } \\
\text { signs, properties, means, opportunities } \\
\text { that determine the potential solvent } \\
\text { demand for investment in fixed assets. }\end{array}$ & I.I. Royzman [8] \\
\hline 7 & $\begin{array}{l}\text { Investment attractiveness is an } \\
\text { independent economic category, } \\
\text { characterized not only by the stability } \\
\text { of the financial condition of the } \\
\text { enterprise, the return on capital, stock } \\
\text { prices, and the level of dividends paid. }\end{array}$ & $\begin{array}{lr}\text { E.I. } & \text { Krylov, } \\
\text { V.M. Vlasova, } & \text { M.G. } \\
\text { Egorova, } & \\
\text { I.V. Zhuravkova [9] }\end{array}$ \\
\hline 8 & $\begin{array}{l}\text { Investment attractiveness refers to the } \\
\text { state of the organization in which the } \\
\text { potential owner of the capital } \\
\text { (investor, lender, lessor, etc.) has a } \\
\text { desire to take a certain risk and ensure } \\
\text { the inflow of investments in monetary } \\
\text { and (or) non-monetary form. }\end{array}$ & $\begin{array}{l}\text { D.A. Endovitsky, V.A. } \\
\text { Babushkin, } \\
\text { Baturina et al. [10] }\end{array}$ \\
\hline 9 & $\begin{array}{l}\text { Investment attractiveness of an } \\
\text { enterprise is a set of indicators of its } \\
\text { activity, with the help of which the } \\
\text { most preferred investment behavior is } \\
\text { determined. }\end{array}$ & N.Yu. Tryasitsina [11] \\
\hline
\end{tabular}

Summarizing the definitions and characteristics of the concept of invest-ment attractiveness, it should be noted that the following properties are common to definitions:

- a set of features of the investee that determine the effectiveness of in-vesting in it to achieve the goals of a particular investor; 
employee, compare employees among themselves by the level of their investment attractiveness, and they are systemforming elements of the concept of the investment attractiveness of the employee.

Thus, the investment attractiveness of an employee refers to a set of nec-essary and sufficient characteristics by which the employer (investor) can deter-mine the feasibility of investing in it to achieve investment objectives, including: health status, qualifications, sociability for solving tasks, business reputation, in-terests, and level of employee motivation.

\section{DEVElopment OF A METHODOlOGICAl APPROACH TO ASSESSING THE STAFF INVESTMENT ATTRACTIVENESS}

A methodological approach to assessing the staff investment attractive-ness is considered by us using the following principles:

1. The principle of bilateral assessment. Assessment of the staff invest-ment attractiveness is carried out in two aspects: assessment of the individual in-vestment attractiveness of the employee, assessment of the organizational and economic relations between the employer and employees in the process of mak-ing investments.

2. The principle of necessity and sufficiency of properties. The assessed properties of the employee are determined on the basis of the necessity and suffi-ciency for making a decision on making investments based on forecasting the ex-pected investment efficiency and the likelihood of achieving investment goals. Assessing the investment attractiveness of an employee includes determining the compliance with the investment objectives of the following characteristics: hu-man capital, growth potential of human capital, socioeconomic interests, and mo-tives of work, investment risks.

3. The principle of compliance with investment objectives. The assessment of the properties and characteristics of the employee is carried out in relation to the specific goals of investing in the employee to generate income or other beneficial effect.

A diagram of a methodological approach to assessing the staff investment attractiveness is shown in Figure 1. necessary and sufficient properties by which the employer (investor) can determine the invest-ment attractiveness of the 


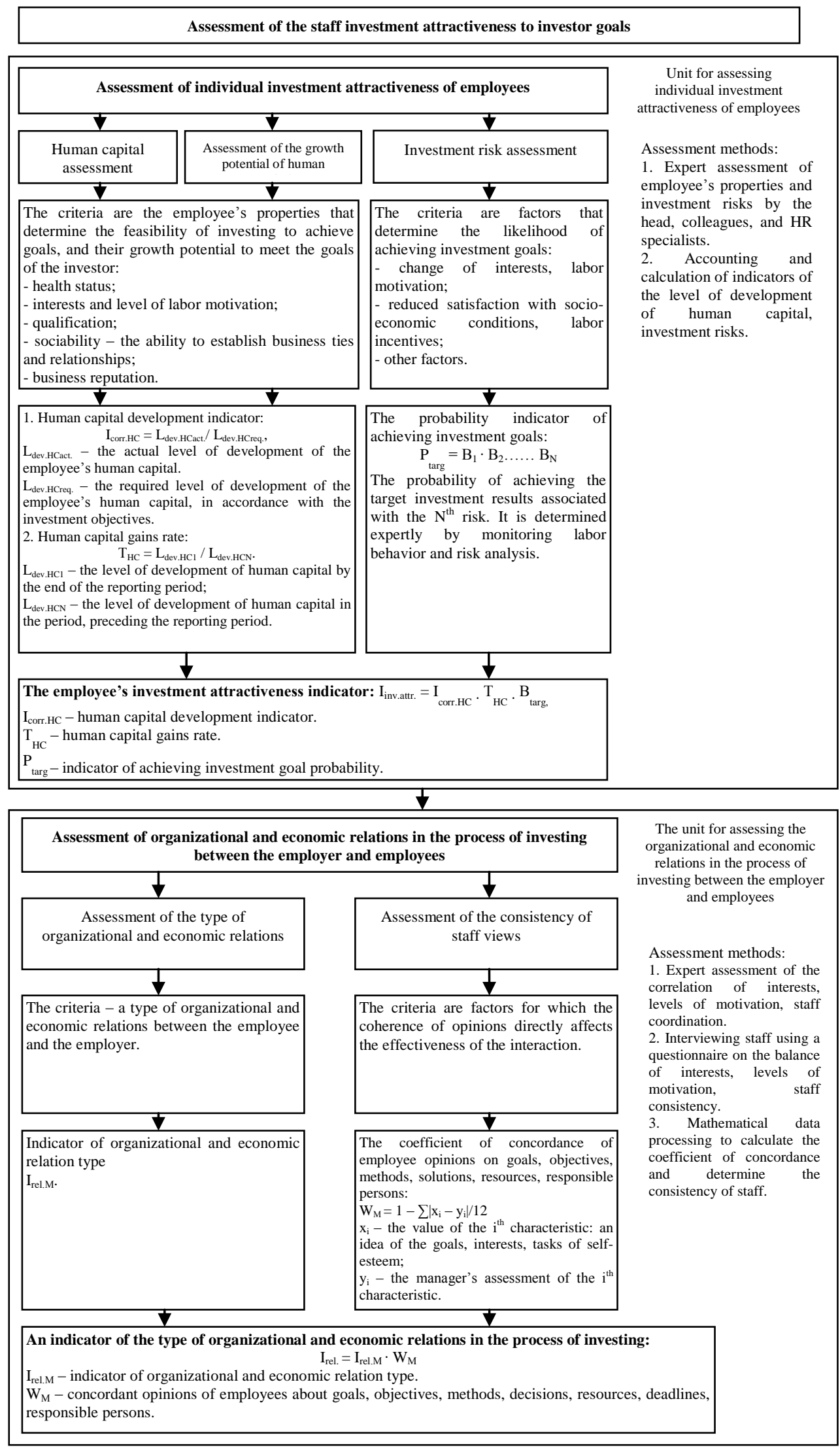

Fig. 1. Diagram of a methodological approach to assessing the staff invest-ment attractiveness 
Pertarg. - performance target indacators for investing in an

According to our definition, the investment attractiveness of an employee refers to the totality of its necessary and sufficient characteristics, on which the employer (investor) can determine the feasibility of making investments to achieve investment objectives, including: health status, qualifications, sociability for solving tasks, business reputation, interests, and level of motivation.

Based on the principle of necessity and sufficiency, it is necessary to eval-uate the following characteristics that significantly affect the effectiveness of in-vestments in an employee and the likelihood of achieving investment goals:

- compliance of the employee's properties with investment objectives: health, qualifications, sociability for solving tasks, business reputation, interests, and level of labor motivation, which, in essence, are human capital of a person;

- the possibility of human capital growth to bring it in line with the goals of investment, as an indicator of which the human capital gains rate can be used;

- the probability of achieving the target investment results, taking into ac-count the main risks of investing in an employee.

Therefore, as an approach to assessing the investment attractiveness of an employee, it is proposed to use the integrated indicator of employee investment attractiveness Iinv.attr., taking into account the indicator of the level of human capi-tal development Icorr.HC, a human capital gains rate $\mathrm{THC}$, an indicator of the prob-ability of achieving investment goals Ptarg.

The developed methodological approach to assessing the type of organiza-tional and economic relations allows us to evaluate the type of organizational and economic relations between the employer (investor) and the employee (recip-ient of investments) that develops in the investment process, determine the ele-ments and directions for improving these relations, coordinate goals, objectives, actions, resources, expected results, evaluate the level of consistency using a concordance coefficient.

\section{STUdY OF THE IMPACT OF THE STAFF INVESTMENT ATTRACTIVENESS ON INVESTMENT EFFICIENCY}

It seems to us theoretically and practically significant to study the impact of the investment attractiveness of employees on the investment efficiency indi-cators in the development of an employee and an enterprise.

In order to assess the investment attractiveness of the employee, we pro-pose to use the indicator of the employee investment attractiveness.

In order to assess the effectiveness of investments in an employee and an enterprise, it is proposed to use an investment performance indicator calculated according to formula 1 .

$$
\text { Perinv. }=\text { Perinv.act } / \text { Pertarg }
$$

Perinv.act - actual performance indicators of investing in an employee de-velopment; employee devel-opment.

In order to establish the influence of the employee's investment attrac-tiveness on the efficiency of investments, we analyzed the results of more than 100 employees of manufacturing, trading, engineering enterprises, enterprises in the service and catering sectors, selected using the "cluster

The analysis was carried out using methods of interviewing employees, employers, represented by owners, directors, an employer's assessment, and self-assessment by employees of their investment attractiveness indicators, account-ing and calculation of investment performance indicators.

As a result, an empirical dependence of the impact of the investment at-tractiveness indicator of an employee Icorr.HC on the effectiveness of investments in the development of an employee Perinv. has been established. (see Fig. 2).

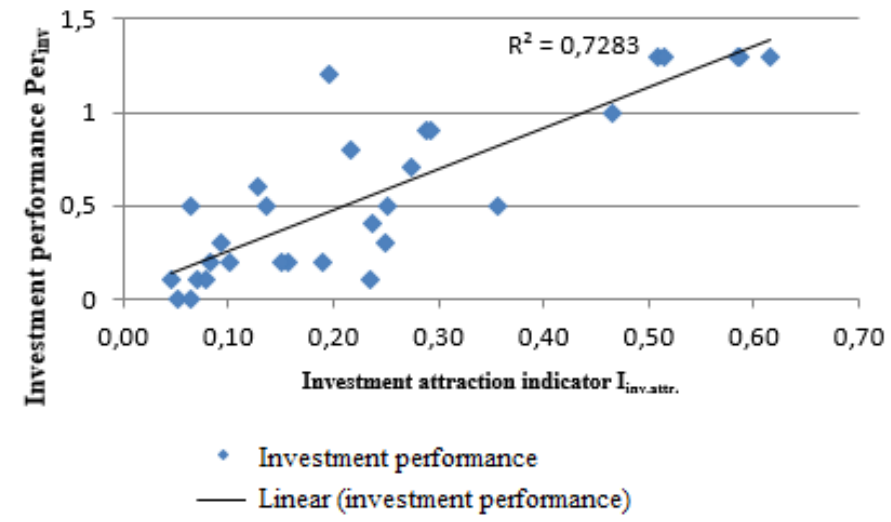

Fig. 2. The dependence of investment performance on the indicator of employee investment attractiveness

As can be seen from Figure 2, the employee investment performance directly depends on the indicator of his/her investment attractiveness $\mathrm{I}_{\text {inv.attr. }}$, which takes into account the human capital of the employee, the dynamics of its development, as well as the risks associated with investing in a particular person.

In order to achieve the objectives of our study, it is advisable to determine the relationship not only between the investment attractiveness of the employee and the effectiveness of investing in him/her, but also to establish the influence of the type of organizational and economic relations that develop between the employee and the employer in the investment process. In our opinion, both of these factors play a crucial role and have a decisive influence on the effectiveness of investment and should be taken into account when assessing and managing the staff investment attractiveness.

As a result of accounting, calculation, analysis of indicators of investment attractiveness of employees $\mathrm{I}_{\text {inv.attr., }}$, organizational and economic relations between employees and the employer in the process of investing $\mathrm{P}_{\text {corr. }}$ more than 100 employees of manufacturing, trading, engineering enterprises, enterprises in the field of services and catering, selected using the "cluster sample" method, we have established a pattern sample" method. 
- mutual enthusiasm for work and self-development;

- a manifestation of the employee's initiative for selfdevelopment and development of the enterprise;

- high responsibility;

- high efficiency and effectiveness of investments in an employee's devel-opment. Actual results of investing in an employee equal to or more than the tar-get ones: Perinv.act $\geq$ Perinv.targ.

The staff of the Group 1 can be entrusted with the most important tasks of the enterprise and staff development.

The Group 2 of personnel "a set of attractive investment employees" is characterized by:

- high individual investment attractiveness of employees, but low interest, coordination of interaction;

- inconsistency of interests, goals, tasks, actions, expected results of the mutual development of the employer (investor) and employees (recipients of in-vestments);

- weak consideration of the interests of employees and, as a consequence, forcing them to work;

- this group, in fact, is a collection of employees with high human potential, but not agreed upon for their goals, objectives, and actions.

- middle productivity and efficiency of investments in an employee's de-velopment. Actual results of investing in an employee are equal to or less than the target ones: Perinv.act $\leq$ Perinv.targ. $\approx 0.5-1$.

Investing in employees of this group without changing the organizational and economic relations between the investor and recipients of the investment is associated with high risks of not receiving the expected results. For example, in modern practice, Russian enterprises often invite highly qualified specialists to carry out important development tasks.

However, employees, falling into conditions in which the employer weakly takes into account and stimulates their main socioeconomic interests, labor mo-tives, the necessary working conditions are not created, goals, tasks, algorithms of actions that are understood by both parties are not coordinated, the expected re-sults are weakly motivated, they cannot effectively solve the tasks and, as a re-sult, the investment goals are not achieved.

When working with the staff of this group, it is recommended to change the type of organizational and economic relations between the employer (inves-tor) and employees (recipients of investments) by identifying the main socioeco-nomic interests, motives of employees, proposing tasks that correspond to their in-terests, creating an understanding among employees how they will be able to satisfy personal motives of work through solving common problems of enterprise development.

The Group 3 of staff is characterized by a "partner" or "developing" type of relationship between the employer and employees that develops in the invest-ment process, but an insufficient level of investment attractiveness of employees: 
insufficient qualifications, labor motivation, and high individual investment risks. The formed "partner" or "developing" type of relationship between the employer and the employee is a necessary, but not sufficient condition for achieving the expected goals of staff investment. Low qualifications, interest in the business, employee satisfaction with the working conditions at the enterprise create high investment risks.

When interacting with employees of this group, employers are encouraged to develop and coordinate measures to increase individual investment attractive-ness by developing a human capital and reducing investment risks.

The purpose of these measures is to increase the individual investment at-tractiveness of employees, reduce investment risks. Actual results of investing in an employee are equal to or less than the target ones: Perinv.act $\leq$ Perinv.targ. $\approx 0.5-1$.

The Group 4 of staff is characterized by a "coercive" or "destructive" type of relationship between the employer and employees, as well as a low level of in-vestment attractiveness of the employees themselves. This staff is characterized by:

- inconsistency of interests, goals, tasks, actions, expected results of the mutual development of the employer and employees;

- Inconsistency of a human capital of employees with investment objec-tives;

- low motivation of participants to mutual development and self-development;

- lack of initiative on the part of employees to participate in the develop-ment of the enterprise;

- low effectiveness and efficiency of investments in an employees' devel-opment. Actual results of investing in an employee are much lower than target ones or equal to zero: Perinv.act $<<$ Perinv.targ. $\approx 0-0.5$.

The studies made it possible to substantiate and empirically confirm the hypothesis about the influence of the individual investment attractiveness of em-ployees and the type of organizational and economic relations that develop be-tween the employee and the employer on the efficiency of investing in staff, and also substantiate the theoretical dependence of this influence (see Figure 4).
Type of relationship between employer



Fig.. 4. The influence of the employee's investment attractiveness and the type of organi-zational and economic relations between the employee and the employer that develop in the investment process on investment efficiency

Thus, the studies conducted allowed us to conclude that the investment efficiency in staff, which is understood as the ratio of actual investment results to target, is determined by the individual investment attractiveness of the employee, taking into account the investment risks and the type of organizational and eco-nomic relations that develop between the employer and the employee in the pro-cess investing.

In order to increase the investment efficiency in staff, the employer needs to form a "developing" and "partner" type of organizational and economic rela-tions and increase the individual investment attractiveness of employees.

\section{DEVELOPMENT OF GUIDELINES FOR IMPROVING THE STAFF INVESTMENT ATTRACTIVENESS}

Based on the theoretical and empirical studies, we have developed guide-lines for improving the staff investment attractiveness.

The common goal and principle of increasing the staff investment attrac-tiveness is to increase investment efficiency by developing individual investment attractiveness of employees and improving organizational and economic relations between the employee and employers, between employees in the process of making investments.

Tasks, methods, tools, measures to increase the staff investment attrac-tiveness are determined by factors affecting the efficiency of investments in the development of employees (see Table 2). 
TABLE II. TASKS, METHODS, MEANS, AND FORMS OF EVENTS TO INCREASE THE STAFF INVESTMENT ATTRACTIVENESS

\begin{tabular}{|c|c|c|c|}
\hline No. & Tasks & Methods and means & Forms of events \\
\hline 1 & $\begin{array}{l}\text { Improving the } \\
\text { organizational and } \\
\text { economic relations } \\
\text { between the } \\
\text { employee and the } \\
\text { employer the by } \\
\text { moving to the } \\
\text { "partner" "developing" type. }\end{array}$ & $\begin{array}{l}\text { 1. Search, definition, coordination of socioeconomic } \\
\text { interests, labor motives, which can be satisfied by solving } \\
\text { common problems of the enterprise and staff } \\
\text { development. } \\
\text { 2. Material and social stimulation of the activation of } \\
\text { interests and motives of employees in relation to self- } \\
\text { development and development of the enterprise. } \\
\text { 3. Coordination of interests, goals, tasks, actions, } \\
\text { expected results of the mutual development of intangible } \\
\text { assets of an employee and an employer. }\end{array}$ & $\begin{array}{l}\text { 1. Individual interviews of the employer (investor) and employees } \\
\text { (recipients of investments). } \\
\text { 2. Joint meetings on the development of the enterprise and personnel. } \\
\text { 3. Inclusion in the functional of managers, specialists, and working } \\
\text { functions for the development of staff human capital and human capital of } \\
\text { employees. } \\
\text { 4. Inclusion in the remuneration system of compensation for achieving the } \\
\text { target results of the development of the enterprise and personnel. }\end{array}$ \\
\hline 2 & $\begin{array}{ll}\text { Improving } & \text { the } \\
\text { investment } & \\
\text { attractiveness } & \text { of } \\
\text { employees. } & \end{array}$ & $\begin{array}{l}\text { 1. Development of the staff human capital of the } \\
\text { enterprise. } \\
\text { 1.1. Maintaining and improving the health status of staff. } \\
\text { 1.2. Further training of employees, mastering the } \\
\text { necessary competencies through systematic training. } \\
\text { 1.3. Increasing staff motivation to the level of } \\
\text { "involved", "enthusiastic" by identifying and increasing } \\
\text { the satisfaction of the main socioeconomic interests of } \\
\text { employees by solving common problems of the } \\
\text { enterprise development. } \\
\text { 1.4. The development of business relations and employee } \\
\text { relations necessary for solving the tasks of staff and the } \\
\text { enterprise development. } \\
\text { 1.5. Formation of an exsellent business reputation of staff } \\
\text { and enterprises based on highly effective work. } \\
\text { 2. Reducing the risks of investing in an employee. }\end{array}$ & $\begin{array}{l}\text { 1.1. Clinical examination of staff, the implementation of wellness } \\
\text { programs, sanatorium-and-spa treatment, etc. } \\
\text { 1.2. Developing certification, self-study tasks, and enterprise development } \\
\text { tasks, standardization of functions and business processes, simulation- } \\
\text { modeling seminars. } \\
\text { 1.3. Individual interviews, developing certifications, meetings on the } \\
\text { development of the enterprise, staff, the purpose of which are to } \\
\text { determine and increase the satisfaction of the socioeconomic interests of } \\
\text { employees by solving common problems of enterprise development. } \\
\text { 1.4. Search, establishment of business relations with specialists, } \\
\text { organizations, and other partners necessary to solve the tasks and achieve } \\
\text { the goals of the enterprise and staff development. } \\
\text { 2. Identification of individual investment risks for each employee, } \\
\text { discussion and coordination of measures with employees to reduce } \\
\text { investment risks to an acceptable level. }\end{array}$ \\
\hline
\end{tabular}

In the practical activities of modern enterprises, the main problems of in-creasing the staff investment attractiveness are as follows:

- lack of a unified methodology for assessing the investment attractiveness of an employee that is clear to every employee;

- inconsistency of the common goal, objectives, development plans of a human capital with the interests of staff or individual groups of employees;

- low motivation to increase investment attractiveness among the subjects of the enterprise: owner, management, employees;
- opportunism on the part of the owner, management, staff in relation to increasing investment attractiveness (following only their own interests, including fraudulently);

- "formal" attitude to various forms of the staff development of a human capital: career plans, staff professional development, continuing education pro-grams, etc.;

- inconsistency of the plans for the development of a human capital be-tween interacting entities (owner, management, personnel): tasks, algorithms for their solution, resources, deadlines.

The solution to the above problems of increasing the staff investment at-tractiveness is possible through the formation of a uniform investment attractive-ness management system for the entire enterprise. The functions of the staff in-vestment attractiveness management system are shown in Table 3.

TABLE III. FUNCTIONS FOR MANAGING THE STAFF INVESTMENT ATTRACTIVENESS

\begin{tabular}{|l|l|l|}
\hline No. & Management function staff investment attractiveness & Methods, techniques, algorithms for managing the staff investment attractiveness \\
\hline 1 & $\begin{array}{l}\text { Determining the goals of the enterprise development and the } \\
\text { staff investment attractiveness }\end{array}$ & Strategic planning methods for the enterprise and staff development \\
\hline 2 & $\begin{array}{l}\text { Definition and standardization of parameters of business } \\
\text { processes, labor functions, elements of staff human capital in } \\
\text { accordance with the enterprise development strategy }\end{array}$ & $\begin{array}{l}\text { Methods for standardizing business processes, labor functions, elements of staff } \\
\text { human capital }\end{array}$ \\
\hline 3 & $\begin{array}{l}\text { Assessment of the staff investment attractiveness to the } \\
\text { requirements of the enterprise }\end{array}$ & $\begin{array}{l}\text { Methodological approach to assessing the staff investment attractiveness (see } \\
\text { Section 3) }\end{array}$ \\
\hline 4 & $\begin{array}{l}\text { Planning to increase the staff investment attractiveness } \\
\text { relations regarding increasing the staff investment attractiveness } \\
\text { investment attractiveness }\end{array}$ & $\begin{array}{l}\text { Methods for reconciling interests in relation to the goals and objectives of } \\
\text { increasing the staff investment attractiveness }\end{array}$ \\
\hline 5 & $\begin{array}{l}\text { Formation of the necessary level of motivation "involved", } \\
\text { "carried away" to increase the investment attractiveness for the } \\
\text { employer and employees }\end{array}$ & $\begin{array}{l}\text { Methods for reconciling interests in relation to the goals and objectives of } \\
\text { increasing the staff investment attractiveness }\end{array}$ \\
\hline 7 & $\begin{array}{l}\text { Organization and monitoring of tasks to increase the staff } \\
\text { investment attractiveness }\end{array}$ & Staff development control methods \\
\hline
\end{tabular}


expected results, evaluate the level of consistency using a concordance coefficient.

4. The conducted studies have enabled, for the first, to empirically confirm the hypothesis about the direct impact of individual investment attractiveness of employees and the type of organizational and economic relations on the invest-ment efficiency in staff, to describe the characteristics of this influence.

5. The proposed methodological recommendations make it possible to sys-tematically increase the investment efficiency in staff based on the management of its investment attractiveness. Testing of theoretical principles, methods, and techniques for increasing the staff investment attractiveness at small and large enterprises of Sverdlovsk and Chelyabinsk Regions allowed us to conclude that they can be used as a tool to ensure the required dynamics of the innovative development of enterprises and staff under the high competition.

\section{References}

[1] Korkina T.A. Investment Attractiveness of Mining Workers: Concept and Assessment. Mining Informational and Analytical Bulletin (Scientific and Technical Journal). 2009.

[2] Belkin V.N. The Theory of Human Capital of an Enterprise. Yekaterinburg: Institute of Economics, the Ural Branch of the Russian Academy of Sciences, 2012. 400 pp.

[3] Valinurova L.S. Organization of Investment Activity in Industries: Monograph. M.: Paleotip, 2008.

[4] Blank I.A. Fundamentals of Investment Management. SPb.: Nika Center, 2005. P. 265.

[5] Mozgoev A. About Some Terms Used in Investment Processes. Investments in Russia. 2002. No 6. P. 48.

[6] Marx K. Capital: T. K. Marx. M.: Political Literature Publishing House. 1988. $900 \mathrm{pp}$.

[7] Mashkin V.A. Management of Investment Attractiveness of the Rea Sector of the Regional Economy. Industrial North. 2007. No. 9.

[8] Royzman I. The Dynamics of Investment Attractiveness and Investment Competitiveness of Russian Regions in the Medium Term. Investments in Russia. 2009. No. 9. pp. 3-14

[9] Krylov E.I., Vlasova V.M., Egorova M.G., Zhuravkova I.V. An Analysis of the Financial Condition and Investment Attractiveness of the Enterprise: Training Aid for students of higher educational institutions studying in the specialties: "Finance and Credit", "Accounting, Analysis, and Audit", "World Economy", "Taxes and Taxation". M.: Finance and Statistics, 2003. $191 \mathrm{pp}$.

[10] Endovitsky D.A., Babushkin V.A., Baturina N.A. et al. Analysis of the Investment Attractiveness of an Organization: Scientific Edition. Ed. by D.A. Endovitsky. M.: KNORUS, 2010. 376 pp.

[11] Tryasitsina N.Yu. A Comprehensive Assessment of the Investmen Attractiveness of Enterprises. Economic Analysis. 2006. No. 18. P. 5.

[12] Litvinova V.V. Investment Attractiveness and Investment Climate of the Region: Monograph. M.: Financial University, 2013. 116 pp.

[13] Agaeva L.K., Anisimova V.Yu. Investment Attractiveness of the Region: Training Aid. Electronic text and graphic data $(423 \mathrm{~Kb})$ Samara: Samara University Press, 2018.

[14] Le Thi Thuy Nga. Investment Attractiveness of Vietnam. Journal of Economic \& Development. 2010. No. 5.

[15] Pham Ngoc Thang. Analysis of Investment Climate in Vietnam. Journal of Communist. 2009. No. 6 